\title{
Relationships between magnetic parameters, chemical composition and clay minerals of topsoils near Coimbra, central Portugal
}

\author{
A. M. Lourenço ${ }^{1}$, F. Rocha $^{2}$, and C. R. Gomes ${ }^{1}$ \\ ${ }^{1}$ Centre for Geophysics, Earth Sciences Dept., University of Coimbra, Largo Marquês de Pombal, \\ 3000-272 Coimbra, Portugal \\ ${ }^{2}$ Geobiotec Centre, Geosciences Dept., University of Aveiro, 3810-193 Aveiro, Portugal \\ Correspondence to: A. M. Lourenço (ana.lourenco@dct.uc.pt)
}

Received: 6 September 2011 - Revised: 27 February 2012 - Accepted: 28 February 2012 - Published: 14 August 2012

\begin{abstract}
Magnetic measurements, mineralogical and geochemical studies were carried out on surface soil samples in order to find possible relationships and to obtain environmental implications. The samples were taken over a square grid $(500 \times 500 \mathrm{~m})$ near the city of Coimbra, in central Portugal. Mass specific magnetic susceptibility ranges between 12.50 and $710.11 \times 10^{-8} \mathrm{~m}^{3} \mathrm{~kg}^{-1}$ and isothermal magnetic remanence at 1 tesla values range between 253 and $18174 \times 10^{-3} \mathrm{Am}^{-1}$. Chemical analysis by atomic absorption spectrometry shows that the concentration of various toxic elements was higher than the mean background values for world soils. Higher values of susceptibility and toxic elements content were reported near roads and rivers. Urban pollution and road traffic emission seem to be the main influence for these values. A semi-quantitative X-ray diffraction study has been carried out on a representative set of subsamples, using peak areas. Illite (average 52\%), kaolinite (average 55\%), chlorite (average 6\%) and irregular illite-smectite mixed-layers (average $9 \%$ ) are the major clay minerals groups identified. Mineral composition of total fraction confirms the presence of magnetite/maghemite. The clay minerals results point to a contrast in the behavior of the main clay minerals: illite, chlorite, and kaolinite (also, smectite in some samples), which are generally in agreement with the magnetic and geochemical data. The results showed that magnetic measurements are a sensitive, fast, inexpensive and robust method, which can be advantageously applied for studying soils affected by urban and road pollution.
\end{abstract}

\section{Introduction}

In the last $30 \mathrm{yr}$, a growing number of studies using the techniques of magnetism of rocks has been applied to environmental problems, thus creating a new branch of research commonly called "environmental magnetism" (Thompson et al., 1980). This methodology is fast, economic and can be applied in various research fields, such as environmental monitoring, pedology, paleoclimatology, limnology, archeology and stratigraphy. Recent studies have demonstrated the advantages and the potential of the environmental magnetism methods as valuable aids in the detection and delimitation of areas affected by pollution (e.g. Bityukova et al., 1999; Boyko et al., 2004; Blaha et al., 2008; Lu et al., 2009; Matýsek et al., 2008). These methods are based on the assumption that industrial and traffic processes, which use fossil fuel combustion, release into the atmosphere particulate matter (fly ash) containing a significant proportion of magnetic minerals (Flanders, 1999). According to Kapička et al. (2000), the combustion of fossil fuel is one of the main sources of fly ash, which may contain about $10 \%$ of ferrimagnetic iron-oxides, formed as the end-product of hightemperature transformation of primary Fe-sulphides (e.g. pyrite) found in coal (Flanders, 1994). Several toxic metals (e.g. $\mathrm{Pb}, \mathrm{Cd}, \mathrm{Zn}$ and $\mathrm{Cr}$ ) are easily adsorbed on the surface of $\mathrm{Fe}$-oxides, or can be substituted in their crystal lattice during high-temperature formation of fly ashes (e.g. Strzyszcz et al., 1996).

One parameter often used in environmental magnetism studies is the magnetic susceptibility. This parameter is easy to measure and does not involve the destruction of the sample, therefore, left available for additional analyses. The measurement of the magnetic susceptibility of the surface soil layers has been used as a proxy to contamination from different pollution sources, diffuse and stationary (Gomes et al., 2006; Hoffmann et al., 1999). Establishing a link between the concentration (and characteristics) of ferrimagnetic minerals and the heavy metal contents has been a challenge for a number of authors. The use of magnetic measurements as a proxy for chemical methods is possible because pollutants and magnetic particles are genetically related (e.g. Hanesch and Sholger, 2002). Several studies report a positive 
correlation between levels of toxic elements and high values of magnetic susceptibility (e.g. Heller et al., 1998; Lourenço, 2003; Gautam et al., 2005; El Baghdadi et al., 2011; Karimi et al., 2011; Meena et al., 2011; Yang et al., 2011).

The magnetic properties of soils proved to be suitable parameters as they reflect the various degrees of contamination due to industrial activities. Atmospheric deposition of fly ashes on land surfaces and vegetation cover leads to an enhanced magnetic signal. Its concentration can be easily detected by measuring the magnetic susceptibility of the surface (e.g. Lecoanet et al., 1999). In addition, any soil contamination can affect groundwater. Mapping of the magnetic properties of topsoils has been used in several countries as a proxy to anthropogenic pollution (Dearing et al., 1996a; Scholger, 1998; Petrovský et al., 2000; Lecoanet et al., 2001; Lourenço, 2003; Moreno et al., 2003; Strzyszcz and Ferdyn, 2005; Chaparro et al., 2006; Gomes et al., 2007; Kapička et al., 2008; Lu et al., 2009). Magnetic parameters measured in soil profiles provide information that allows us to establish a limit in depth indicating the transition from the "polluted" to the deeper, "unpolluted" zone in contaminated natural soil (Blaha et al., 2008).

Magnetic methods should be considered as a first choice and an appropriate strategy when conducting surveys (Blaha et al., 2008) and they can be a helpful indicator when targeting and selecting sampling sites for subsequent geochemical analyses. These methods allow us to target the area most affected by pollution near roads and highways (Hoffmann et al., 1999; Knabb et al., 2001; Maher et al., 2008; Kim et al., 2009; Marié et al., 2010) or industrial units, such as steel smelters (Ďurža, 1999; Chaparro et al., 2002; Hanesh et al., 2003; Rosowiecka and Nawrocki, 2010), power plants (Strzyszcz et al., 1996; Kapička et al., 1999; Veneva et al., 2004) and cement plants (Gołuchowska, 2001). These are the preferred areas for sampling in order to investigate the level of contamination by toxic elements like heavy metals, with consequent benefits in saving time, manpower and materials. Any protective and remedial actions will be applied more rationally when being restricted to these areas. In addition to the studies mentioned above, which can be described as the classic use of environmental magnetism as they aim to quantify pollution levels in air, sediments and soils, some authors have been concerned with the standardization of procedures and compatibility of instruments used in previous research (Schibler et al., 2002). Repeatability and reproducibility of magnetic parameters measurements are also discussed by Boyko et al. (2004).

The main goals of our study are: (1) to measure the magnetic parameters, such as magnetic susceptibility $(\chi)$, anhysteretic remanent magnetization (ARM) and isothermal remanent magnetization (IRM); (2) to study the magnetic parameters, the chemical contents and the mineralogical composition in order to characterize the soil; (3) to relate magnetic parameters and chemical contents with pollution levels so as to identify the major pollution sources; (4) to find possible

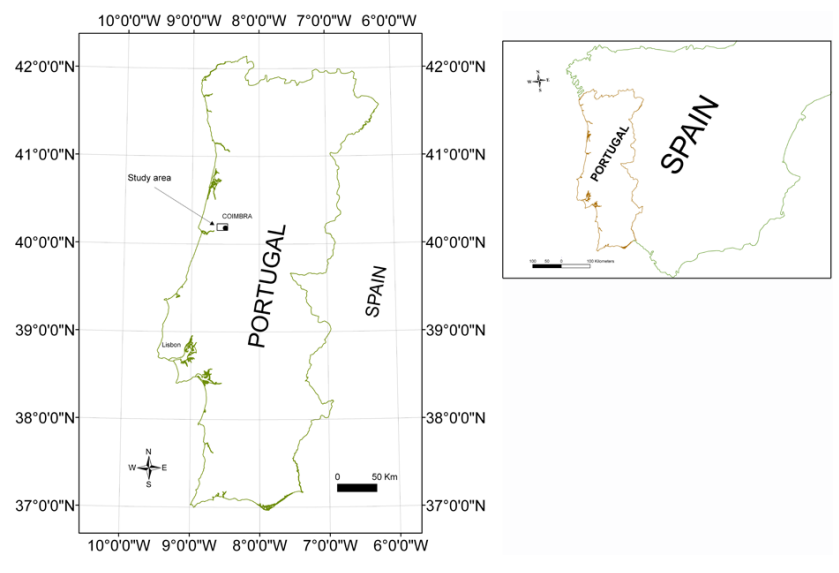

Fig. 1. Location of the study area.

relationships between the measured parameters; and (5) to analyze the results of the magnetic parameters in order to obtain environmental implications.

\section{Methodology}

\subsection{Area description, field work and soil sampling}

The study area (Fig. 1) is located in central-northwest Portugal near the city of Coimbra (latitude $40^{\circ} 13^{\prime \prime}$ ). There are no power plants or other industrial units in this area. The climate is mild Mediterranean. Mean annual precipitation is around $950 \mathrm{~mm}$ and mean annual temperature is $15^{\circ} \mathrm{C}$. Prevailing wind direction is SE in November, December, January and February and NW in the remaining months. Sandstones and limestones are the dominant lithologies.

This area is mainly occupied by the alluvial plain of the Mondego River with numerous agricultural fields and drainage channels; it is also crossed by road EN-111-1, which connects the cities of Coimbra and Figueira da Foz, and by the A1 motorway. Human presence in the area goes back over $10000 \mathrm{yr}$. Prevailing soil types in the area are Fluvisols, according to FAO/UNESCO classification (FAO, 2006). The samples (104) were collected using a square grid of $500 \mathrm{~m}$ by $500 \mathrm{~m}$, but also in other selected locations (Fig. 2). Samples were also collected at intervals of $1 \mathrm{~m}$ along two horizontal profiles located perpendicular to the main roads ( $5 \mathrm{~m}$ on road bi-sides, Fig. 8 ). Soil material was sampled from the upper $20 \mathrm{~cm}$. For each sampling site, a composite sample of $1 \mathrm{~kg}$ was produced from four sub samples. These were taken from the sampling point towards the cardinal directions (in an area $1 \times 1 \mathrm{~m}$ ) after having removed the vegetation layer, which consists of typical grass (Lolium perenne, Poa pratensis and Poa trivialis). Samples were collected after several days of dry weather and placed in plastic bags then sealed and labeled. 


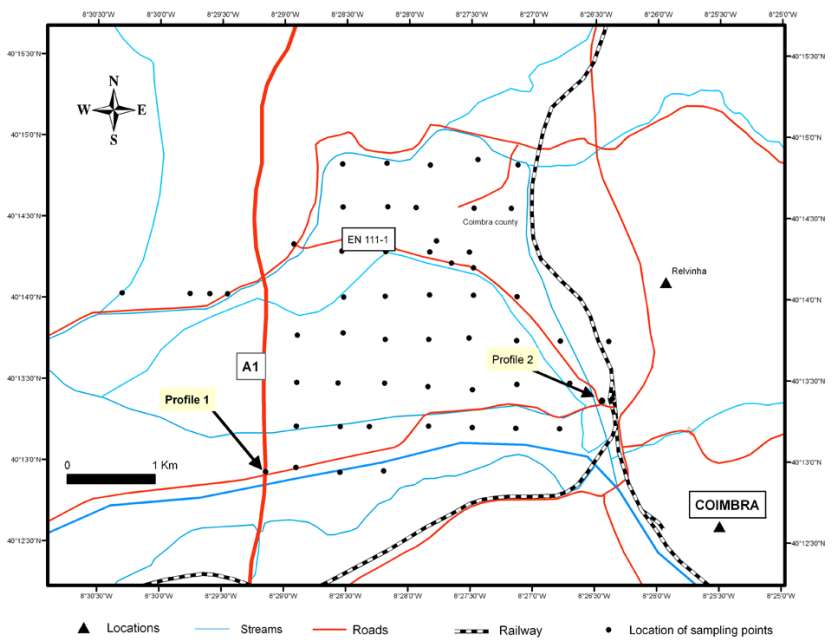

Fig. 2. Location of sampling points and profiles.

\subsection{Laboratory work}

\subsubsection{Magnetic measurements}

In order to discover the concentration and nature of magnetic carriers, several magnetic parameters were measured and relations between them were analyzed.

The magnetic parameters which yielded information about concentration, magnetic mineralogy and grain size of the main magnetic minerals are listed in Table 1 . All the samples were dried at a maximum temperature of $40^{\circ} \mathrm{C}$ to avoid any possible mineralogical changes (Maher, 1986), then passed through a $2 \mathrm{~mm}$ sieve. Two types of magnetic susceptibility measurements were carried out.

Low-field magnetic susceptibility was measured using a magnetic susceptibility meter MS2, Bartington Instruments Ltd., linked to a MS2B dual frequency sensor (470 and $4700 \mathrm{~Hz})$. By using this sensor, it was possible to estimate frequency-dependent $\kappa_{\mathrm{fd}}\left(\kappa_{\mathrm{fd}}\right.$ in $\left.\%\right)$. The frequencydependent susceptibility was calculated as difference percentage $\kappa_{\mathrm{fd}}=100 \times\left(\kappa_{\mathrm{lf}}-\kappa_{\mathrm{hf}}\right) / \kappa_{\mathrm{lf}}$ (Table 1). This parameter enables the assessment of the significance of ultrafine superparamagnetic magnetite grains (Dearing et al., 1996b); this information is important for distinguishing between pedogenic and anthropogenic origins. Mass specific susceptibility was determined with an AGICO Kappabridge magnetic susceptibility meter, model KLY-4S. At least three susceptibility measurements were obtained and the average value was used. A regression was then calculated between the mass specific and the volume specific measurements. The regression equations were used to calculate mass specific values for all samples in the unit $10^{-8} \mathrm{~m}^{3} \mathrm{~kg}^{-1}$ (Hanesh and Sholger, 2002).

Anhysteretic remanent magnetization (ARM), here expressed as susceptibility of ARM $\left(\kappa_{\mathrm{ARM}}\right)$, was measured on a MOLSPIN Minispin magnetometer. It was measured after demagnetization in an AF field of $100 \mathrm{mT}$, inducing a DC biasing field of $0.05 \mathrm{mT}$ by using an AGICO AF demagnetizer and an anhysteretic attachment AGICO LDA-3/AMU1. Isothermal remanent magnetization up to $3 \mathrm{~T}$ was imparted in a MMPM9 magnetizer, and then measured on a MOLSPIN Minispin magnetometer.

The magnetic parameter Hard IRM (HIRM), broadly indicative of antiferromagnetic minerals, was calculated using the formula: $\mathrm{HIRM}=0.5 \times\left(\mathrm{SIRM}_{\mathrm{IRM}} \mathrm{I}_{-300 \mathrm{mT}}\right)(\mathrm{e} . \mathrm{g}$. Alargasamy, 2009), were SIRM $=\mathrm{IRM}_{1 \mathrm{~T}}$.

\subsubsection{Chemical analyses}

Chemical analyses were carried out using the sample digestion method commonly used for determining the mobile parts of elements, which are more easily absorbed by plants. The samples were dried at $40^{\circ} \mathrm{C}$, then homogenized, quartered and passed through a $180 \mu \mathrm{m}$ plastic sieve. Representative $0.5 \mathrm{~g}$ subsamples were digested with a mixture of $\mathrm{HNO}_{3}+\mathrm{HClO}_{4}+\mathrm{HF}$. Solutions were analyzed for $\mathrm{Zn}, \mathrm{Ni}$, $\mathrm{Co}, \mathrm{Cr}, \mathrm{Cu}$ and $\mathrm{Pb}$ using Atomic Absorption Spectrometry (Perkin-Elmer 2380, air-acetylene flame).

\subsubsection{X-ray diffraction analysis}

The mineral composition was determined both on unoriented powder mounts for total sample analysis and on oriented aggregates for the clay fraction ones. The clay fractions were separated by sedimentation according to Stokes law, using $1 \%$ sodium hexametaphosphate solution to avoid flocculation. XRD measurements were made with a Philips PW1130/90 and X'Pert PW3040/60 equipment using $\mathrm{Cu} \mathrm{K} \alpha$ radiation. To study the soil clay-fraction mineralogy, oriented mounts were prepared by pipetting $1 \mathrm{ml}$ of the clay suspensions onto glass slides and allowing them to air dry. The air dried, glycerol and heat $\left(500^{\circ} \mathrm{C}\right)$ treated slides were scanned from $2^{\circ}$ to $20^{\circ} 2 \theta$. The estimates of the mineral abundances were based on subsequent peak intensities. For the semi-quantification of the identified principal clay minerals, peak areas of the specific reflections were calculated and weighted (Lapa and Reis, 1977). The following peaks were used: illite - $10 \AA$ peak, in natural specimen; kaolinite $-7 \AA$ peak, in natural specimen; chlorite $-7 \AA$ and $14 \AA$ peaks, in $500^{\circ} \mathrm{C}$ heated specimen and smectite $-17 \AA$ in glycerol specimen. The intensities were corrected using recommended reflection powers (Galhano et al., 1999; Oliveira et al., 2002; Martins et al., 2007): smectite $17 \AA$ peak area was divided by 4 , llite $10 \AA$ peak area by 0.5 , chlorite $7 \AA$ peak area (after $500^{\circ} \mathrm{C}$ heating) by 1.25 and kaolinite $7 \AA$ peak area (depleted of the previously calculated chlorite area) by 1 . Illite, chlorite and kaolinite crystallinity indices were also determined: illite crystallinity was assessed measuring the width of the peak at halfheight of the first basal reflections (Kübler, 1964; Dunoyer de Segonzac, 1969), kaolinite crystallinity was estimated through the ratio between $7 \AA$ peak half-height width and the height of this peak, after 
Table 1. Magnetic parameters referred to in the text and their basic interpretation (according to Jordanova et al., 2010; Walden and Ballantyne, 2002).

\begin{tabular}{|c|c|c|c|}
\hline $\begin{array}{l}\text { Magnetic } \\
\text { parameters }\end{array}$ & $\begin{array}{l}\text { Units } \\
\text { (SI) }\end{array}$ & Definition & Significance \\
\hline$\chi$ & $10^{-8} \mathrm{~m}^{3} \mathrm{~kg}^{-1}$ & $\begin{array}{l}\text { Mass specific susceptibility } \\
\chi=M / \rho H(\rho \text {-density; } M-\text { magnetic moment; } \\
H-\text { applied field })\end{array}$ & $\begin{array}{l}\text { It reflects the concentration of strongly } \\
\text { magnetic Fe oxides } \\
\text { (magnetite/maghemite). It also reflects } \\
\text { the presence of paramagnetic minerals, }\end{array}$ \\
\hline$\kappa$ & $10^{-5} \mathrm{SI}$ & Magnetic volume susceptibility $(\kappa=\chi \times \rho)$ & $\begin{array}{l}\text { and it is important when ferromagnetic } \\
\text { minerals sensu lato are not dominant. }\end{array}$ \\
\hline \multirow[t]{2}{*}{$\kappa_{\mathrm{fd}}$} & $\%$ & $\begin{array}{l}\text { Percent frequency dependent magnetic suscep- } \\
\text { tibility }-\kappa_{\mathrm{fd}}=100 \times\left(\kappa \kappa_{\mathrm{lf}}-\kappa \kappa_{\mathrm{hf}}\right) / \kappa_{\mathrm{lf}} \\
\kappa \kappa_{\mathrm{lf}}-\text { susceptibility measured at low frequency } \\
(0.47 \mathrm{kHz})\end{array}$ & $\begin{array}{l}\text { Presence of superparamagnetic grains } \\
(<20 \mathrm{~nm})\end{array}$ \\
\hline & & $\begin{array}{l}\kappa \kappa_{\mathrm{hf}}-\text { susceptibility measured at higher fre- } \\
\text { quency }(4.7 \mathrm{kHz})\end{array}$ & \\
\hline $\operatorname{IRM}_{1 \mathrm{~T}}(\mathrm{SIRM})$ & $10^{-3} \mathrm{Am}^{-1}$ & Saturation isothermal remanence & $\begin{array}{l}\text { Presence of stable remanence-carrying } \\
\text { minerals }\end{array}$ \\
\hline$S$-ratio & dimensionless & $\begin{array}{l}S_{-100}=-\mathrm{IRM}_{-100 \mathrm{mT}} / \mathrm{SIRM} \\
S_{-300}-\mathrm{IRM}_{-300 \mathrm{mT}} / \mathrm{SIRM}\end{array}$ & $\begin{array}{l}\text { Such ratios can be used to discriminate } \\
\text { between ferrimagnetic and canted anti- } \\
\text { ferromagnetic mineral types. }\end{array}$ \\
\hline ARM & $10^{-3} \mathrm{Am}^{-1}$ & Anhysteretic remanence & Presence of stable single-domain grains \\
\hline$\kappa_{\mathrm{ARM}}$ & $10^{-5} \mathrm{SI}$ & $\begin{array}{l}\text { Susceptibility of ARM } \\
\kappa_{\mathrm{ARM}}=\mathrm{ARM} h^{-1} \text {, where } h \text { is the intensity of } \\
\text { the DC field }\end{array}$ & $\begin{array}{l}\text { Preferentially increases when stable } \\
\text { single-domain grains are the main } \\
\text { remanence carriers }\end{array}$ \\
\hline HIRM & $10^{-3} \mathrm{Am}^{-1}$ & Hard $\mathrm{IRM}=\left(\mathrm{IRM}_{1 \mathrm{~T}}+\mathrm{IRM}_{-300 \mathrm{mT}}\right) / 2$ & Presence of antiferromagnetic minerals \\
\hline
\end{tabular}

decomposition of chlorite and kaolinite, in air dried aggregates (Abrantes and Rocha, 2007). In order to study the relationship between the crystallinity of clay minerals and the content of toxic metals, a new index, $R$, is also computed for each clay mineral: the amount of phyllosilicates (global clay minerals) computed for the total sample was redistributed between the three main clay minerals (illite, kaolinite and chlorite), according to their relative proportions in the clay fractions (Martins et al., 2007), then this value was multiplied by the index of crystallinity of each main clay mineral.

\subsubsection{Data analysis}

Statistical analysis of the magnetic and chemical data was carried out using SPSS for Windows 18.0 software. Correlation coefficients and the associated level of significance were employed to establish the relationship between heavy metal levels and magnetic parameters. The Spearman correlation was used in order to minimize the influence of extreme values. Mapping of $\chi$ variation was created with ArcGIS 9.2 software.

\section{Results and discussion}

The magnetic measurements are presented in Table 2. Volume magnetic susceptibility, $\kappa_{\mathrm{lf}}$, varies between 6 and $325 \times 10^{-5}$ SI. The mass specific magnetic susceptibility, $\chi$, varies between 12.50 and $710.11 \times 10^{-8} \mathrm{~m}^{3} \mathrm{~kg}^{-1}$ with a mean value of $65.5 \times 10^{-8} \mathrm{~m}^{3} \mathrm{~kg}^{-1}$. A regression was calculated between the mass specific and the volume specific measurements (Fig. 3), and the regression equations used to calculate mass specific values for all samples in the unit $10^{-8} \mathrm{~m}^{3} \mathrm{~kg}^{-1}$ by using the logarithmic susceptibility values because the distribution of the values is approximately lognormal (e.g. Hanesh and Scholger, 2002; Hanesh et al., 2003; Boyko et al., 2004; Kapička et al., 2008). The dispersion of the mass specific susceptibility values is shown in Fig. 4.

Acquisition curves of IRM up to $3 \mathrm{~T}$ (Fig. 5) suggest the presence of ferrimagnetic structures such magnetite/maghemite. $\mathrm{IRM}_{1 \mathrm{~T}}$ varies between $252.50 \times 10^{-3} \mathrm{Am}^{-1}$ and $18174.00 \times 10^{-3} \mathrm{Am}^{-1}$, with a mean value of $1903.30 \times 10^{-3} \mathrm{Am}^{-1}$. Values of $\mathrm{IRM}_{1 \mathrm{~T}}$ show a high correlation with the $\chi$ values ( $r$ of Spearman $=0.9$ ) (Fig. 6). The samples taken near streams have similar IRM $\mathrm{I}_{1}$ values within a relatively narrow range (from $2000 \times 10^{-3} \mathrm{Am}^{-1}$ to $2800 \times 10^{-3} \mathrm{Am}^{-1}$ ). 
Table 2. Summary statistics of the magnetic measurements.

\begin{tabular}{lrrrrrrr}
\hline & Range & $M$ & Mdn & P10 & P25 & P75 & P95 \\
\hline$\chi\left(10^{-8} \mathrm{~m}^{3} \mathrm{~kg}^{-1}\right)$ & $12.5-710.1$ & 65.5 & 60.2 & 32.6 & 43.4 & 70.1 & 103.8 \\
$\kappa_{\text {lf }}\left(10^{-5} \mathrm{SI}\right)$ & $6.0-325.0$ & 31.7 & 26.0 & 12.3 & 19.0 & 33.3 & 61.4 \\
$\kappa_{\mathrm{hf}}\left(10^{-5} \mathrm{SI}\right)$ & $6.0-79.0$ & 25.7 & 25.0 & 11.2 & 17.0 & 30.0 & 45.0 \\
$\kappa_{\mathrm{fd}} \%$ & $0.0-13.6$ & 6.0 & 6.7 & 0.0 & 3.3 & 8.7 & 12.0 \\
$\mathrm{IRM}_{1 \mathrm{~T}}\left(10^{-3} \mathrm{Am}^{-1}\right)$ & $252.5-18174.0$ & 1909.3 & 1480.9 & 721.1 & 1106.3 & 2112.9 & 3587.9 \\
$S_{-300 \mathrm{mT}}$ & $0.8-1.0$ & - & - & - & - & - & - \\
$S_{-100 \mathrm{mT}}$ & $0.4-1.0$ & - & - & - & - & - & - \\
$\mathrm{ARM}\left(10^{-3} \mathrm{Am}^{-1}\right)$ & $493.0-4.4$ & 40.9 & 29.7 & 12.5 & 17.9 & 48.0 & 100.3 \\
$\kappa_{\mathrm{ARM}}\left(10^{-5} \mathrm{SI}\right)$ & $0.8-94.8$ & 7.6 & 5.7 & 2.4 & 3.4 & 9.2 & 19.3 \\
$\mathrm{SIRM} / \kappa\left(10^{3} \mathrm{Am}^{-1}\right)$ & $7.7-15.2$ & 6.2 & 5.7 & 4.3 & 4.9 & 6.9 & 9.8 \\
HIRM $\left(10^{-3} \mathrm{Am}^{-1}\right)$ & $6.8-192.3$ & 54.3 & 43.8 & 9.5 & 26.4 & 62.4 & 163.3
\end{tabular}

$M$ - arithmetic mean; Mdn - median; $\mathrm{P}$ - percentile.

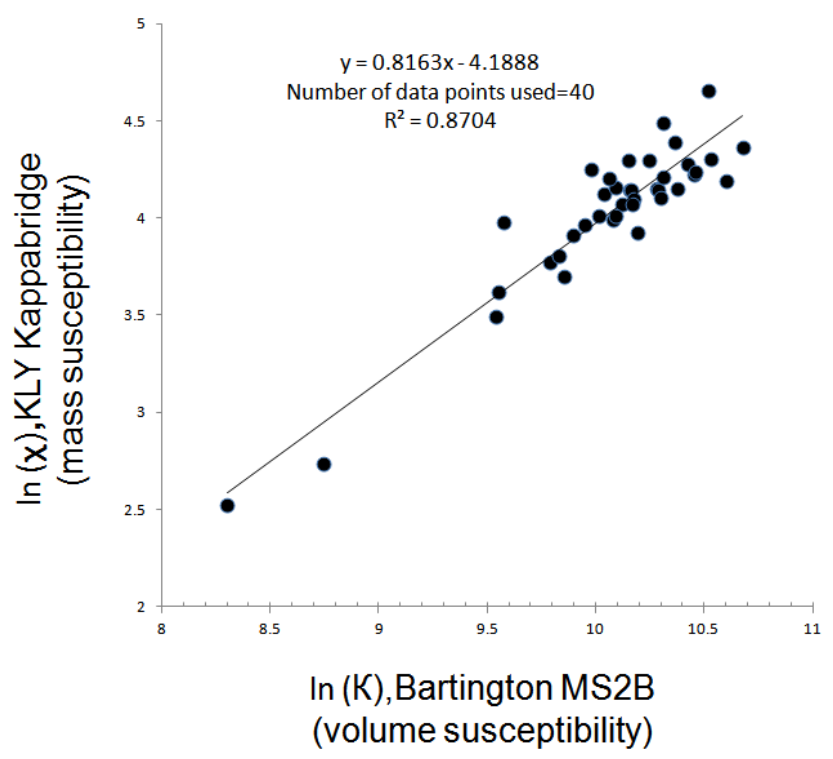

Fig. 3. Calibration curves for the calculation of mass specific susceptibility values $\left(10^{-8} \mathrm{~m}^{3} \mathrm{~kg}^{-1}\right)$ from the volume specific measurements.

The interparametric ratio $\mathrm{SIRM} / \kappa$ is useful to describe grain size and mineralogy type of magnetic particles. This is important to explain the origin of these particles. Both magnetic parameters are displayed in a biplot (Fig. 7). Grain size distributions between $4 \mu \mathrm{m}$ and $>10 \mu \mathrm{m}$ were found. According to Thompson's plot (Thompson and Oldfield, 1986) the peak of magnetite concentration is close to $0.01 \%$.

HIRM can be used as a rough guide to canted antiferromagnetic minerals in a sample (Walden and Ballantyne, 2002; Liu et al., 2007). Samples near the A1 motorway have the higher HIRM values $\left(120.3-192.3 \times 10^{-3} \mathrm{Am}^{-1}\right)$, implying greater concentration of magnetically "harder" (higher coercivity) minerals (e.g. haematite). We think the

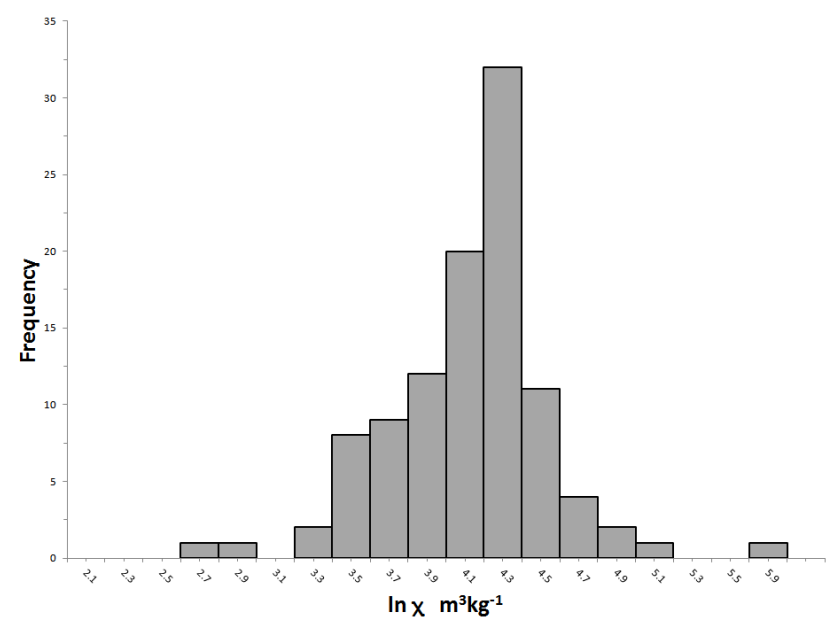

Fig. 4. Histogram of topsoil mass specific susceptibility.

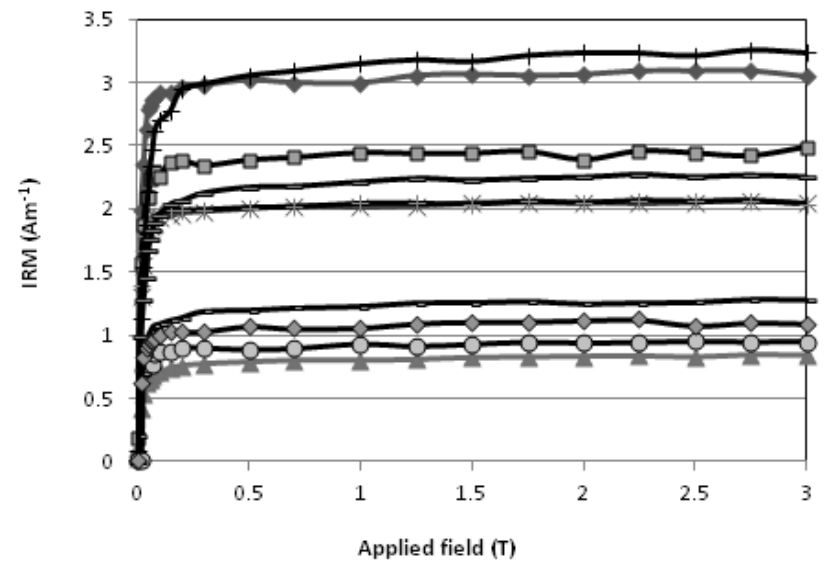

Fig. 5. Acquisition curves of IRM up to $3 \mathrm{~T}$.

Nat. Hazards Earth Syst. Sci., 12, 2545-2555, 2012 


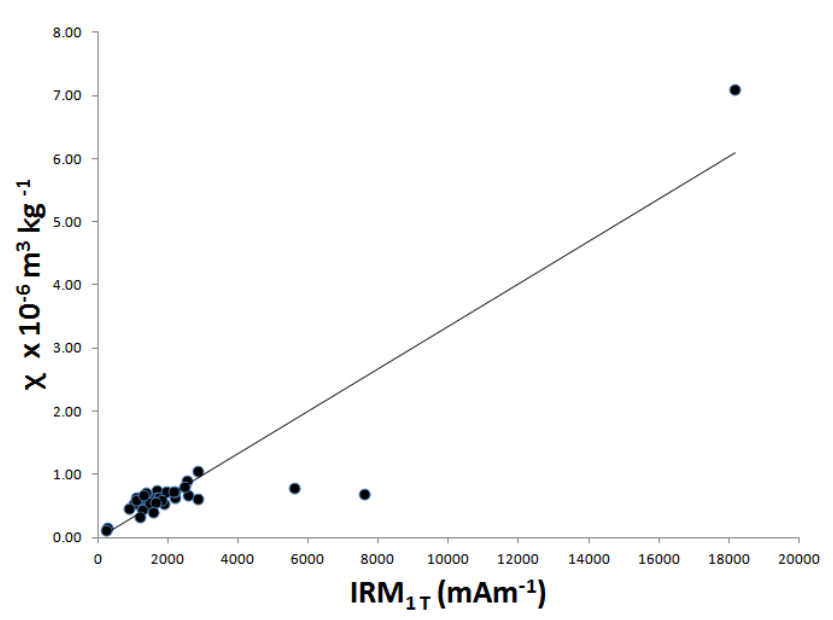

Fig. 6. Correlation between magnetic susceptibility and $\mathrm{IRM}_{1 \mathrm{~T}}$.

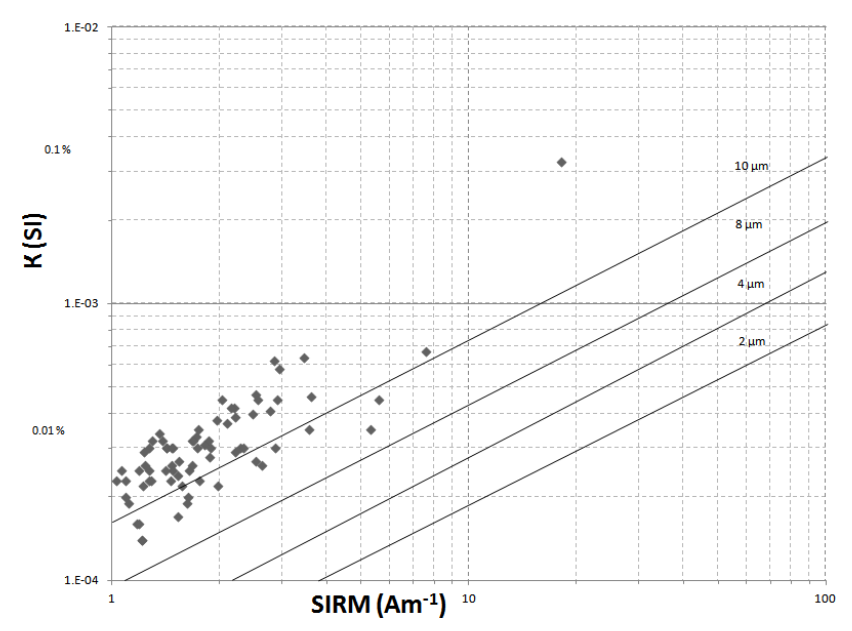

Fig. 7. Thompson's plot (after Chaparro et al., 2004). Magnetite concentration $(\%)$ is displayed on the vertical axis (Thompson and Oldfield, 1986).

origin of these particles is traffic-related (metallic or fly-ash particles produced by abrasion, e.g. brake system, tyres or asphalt).

$\kappa_{\mathrm{ARM}}$ is roughly proportional to the concentration of ferrimagnetic grains in the $0.02-0.5 \mu \mathrm{m}$ (stable single domain) size range (Booth et al., 2005). The lowest $\kappa_{\text {ARM }}$ values indicate that the samples collected in agricultural fields $(0.8-$ $1.4 \times 10^{-5} \mathrm{SI}$ ) contain low to moderate concentrations of stable single domain magnetite.

GIS-based maps were selected due to their capability to portray spatial relationships. The distribution of $\chi$ is shown in Fig. 8. The higher values of magnetic susceptibility are recorded near roads and streams. Near roads, these values are associated with ferrimagnetic material produced by car traffic. The reason for the high values near streams is believed to lie in the accumulation of antropogenic magnetic

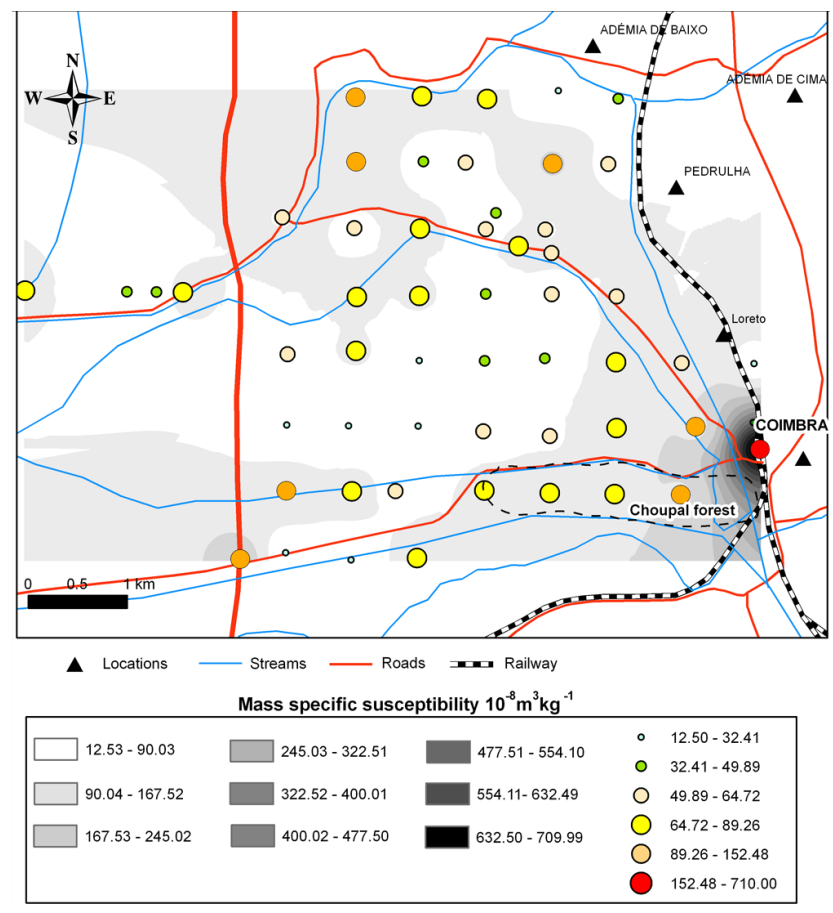

Fig. 8. Spatial variation of $\chi$.

particles during floods, which may result from effluents discharge by urban and industrial areas, but also due to the fact that organic matter (vegetation) near streams can create favorable conditions for the formation of ferrimagnetic iron oxides. Until the Mondego river bed stabilisation in the 1970's the area under study was repeatedly subject to floodings. The samples were collected downstream of the city and for many years, until the construction of wastewater treatment stations, urban sewage was released directly into the Mondego River. Although wind direction does not seem to be very favorable to this transport, the deposition of fly ash produced by Souselas cement plant about $8 \mathrm{~km}$ away northeast (whose chimney filters have recently been improved) may have caused some magnetic signal increase. In the forest area of Choupal, the magnetic susceptibility's high values may be explained by the organic matter content (Mullins, 1977 in Chaparro et al., 2002). The high humus content leads to magnetic particle retention (Hanesch and Scholger, 2005). Near roads, high values result mainly from road traffic (asphalt abrasion, brakes, tires and exhaust fumes).

$S$-ratios can be used to gain information about the magnetic mineralogy (Bloemendal et al., 1992). For example, using the $100 \mathrm{mT}$ acquisition ratio, minerals that are relatively easy to magnetise (e.g. magnetite) have relatively high values (referred to as "soft" (low coercivity) magnetic behaviour). Minerals that show a stronger resistance to magnetisation (e.g. haematite) show relatively low $100 \mathrm{mT}$ acquisition ratios (referred to as "hard" (high coercivity) magnetic behaviour) (Walden and Ballantyne, 2002). Values close to 
Table 3. Summary statistics of the chemical data.

\begin{tabular}{lrrrrrrr}
\hline & Range & $M$ & Mdn & P10 & P25 & P75 & P95 \\
\hline $\mathrm{Zn}$ & $73.60-699.40$ & 386.50 & 124.4 & 88.52 & 103.10 & 154.90 & 446.68 \\
$\mathrm{Ni}$ & $36.00-60.60$ & 48.30 & 48.80 & 43.56 & 46.60 & 53.90 & 58.06 \\
$\mathrm{Co}$ & $2.60-31.60$ & 17.10 & 14.80 & 5.56 & 8.90 & 18.40 & 26.34 \\
$\mathrm{Cr}$ & $21.20-60.80$ & 41.00 & 33.80 & 25.12 & 28.60 & 41.80 & 55.24 \\
$\mathrm{Cu}$ & $19.60-136.80$ & 78.20 & 55.60 & 29.48 & 41.40 & 73.40 & 106.26 \\
$\mathrm{~Pb}$ & $47.20-183.00$ & 115.10 & 70.20 & 56.36 & 60.30 & 88.00 & 155.10 \\
\hline
\end{tabular}

Concentrations in $\mathrm{mg} \mathrm{kg}^{-1} . M$-arithmetic mean; Mdn - median; $\mathrm{P}$ - percentile.

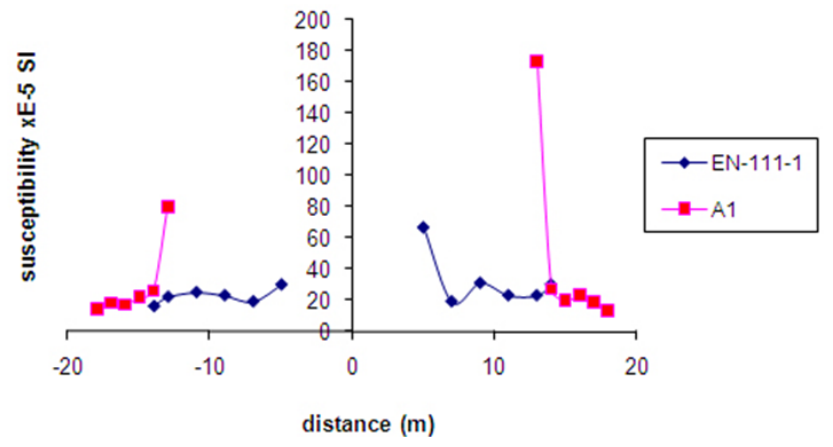

Fig. 9. Variation of susceptibility on road profiles.

1 indicate that magnetically soft grains control the magnetic properties on the sample. The $S_{-100 \mathrm{mT}}$ and the $S_{-300 \mathrm{mT}}$ values range between $0.4-1.0$ and $0.8-1.0$, respectively confirming the presence of ferrimagnetic structures (Lourenço et al., 2011).

The values of $\kappa_{\mathrm{fd}}$ range from 0 to $14 \%$ with an average of $4 \%$. These values are low enough to indicate the SD and MD grains' predominant presence which can be attributed to ferrrimagnetic minerals with possible anthropogenic origin (Maher, 1986; Hay et al., 1997). Some samples however have values of $\kappa_{\mathrm{fd}}>10 \%$ which suggest an important contribution of SP particles (Mohamed et al., 2001). We have studied the variation of $\kappa$ (volume susceptibility) values in horizontal profiles perpendicular to the roads, using collected samples (Lourenço, 2003). The location of these profiles is shown on the map in Fig. 2. The highest values occur near the road's edge (Fig. 9). Spatial distribution of these values seems to be caused by car traffic. These observations are consistent with similar studies (Hoffmann et al., 1999).

Profile 1 held on the A1 motorway shows the roadside topography effect on the distribution of magnetic parameters values. The decrease is possible due to the fact that in this section, the motorway was built on landfill, at a height of about $7-8 \mathrm{~m}$ on adjacent land with a $45^{\circ}$ slope. The washing out of magnetic material from the road can be responsible for the higher values recorded near the road, according to Hoffmann et al. (1999).
Table 4. The values of this study versus the values of the "Soil Geochemical Atlas of Portugal".

\begin{tabular}{crrrrr}
\hline & \multicolumn{2}{c}{ This study } & & \multicolumn{2}{c}{ "Soil Geochemical } \\
& & & & \multicolumn{2}{c}{ Atlas of Portugal" } \\
\cline { 2 - 3 } \cline { 6 - 7 } & Range & $M$ & & Range & $M$ \\
\hline $\mathrm{Zn}$ & $73.60-699.40$ & 386.50 & & $5.00-738.00$ & 59.00 \\
$\mathrm{Ni}$ & $36.00-60.60$ & 48.30 & & $<1.00-880.00$ & 22.00 \\
$\mathrm{Co}$ & $2.60-31.60$ & 17.10 & & $<1.00-84.00$ & 10.00 \\
$\mathrm{Cr}$ & $21.20-60.80$ & 41.00 & & $<1.00-336.00$ & 26.00 \\
$\mathrm{Cu}$ & $19.60-136.80$ & 78.20 & & $<1.00-245.00$ & 21.00 \\
$\mathrm{~Pb}$ & $47.20-183.00$ & 115.10 & & $2.00-585.00$ & 26.00 \\
\hline
\end{tabular}

Concentrations in $\mathrm{m} \mathrm{kg}^{-1} ; M$ - arithmetic mean.

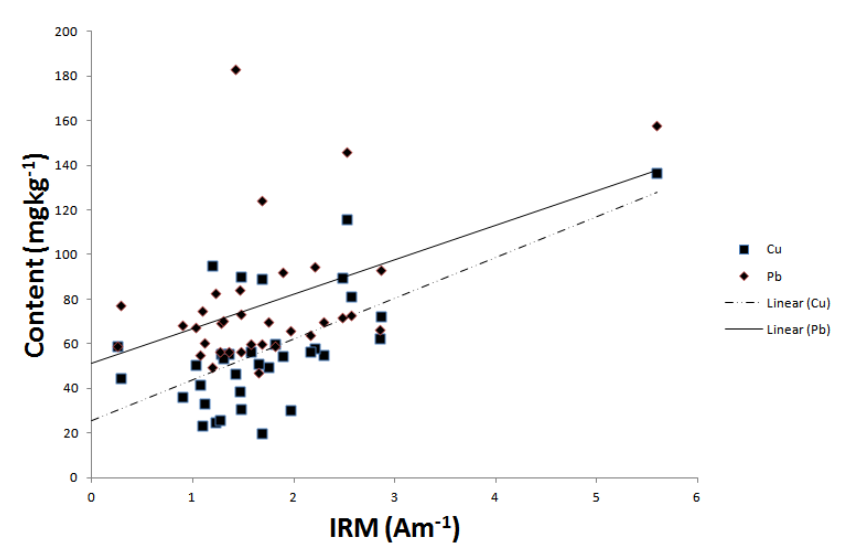

Fig. 10. Correlation between $\mathrm{IRM}_{1 \mathrm{~T}}$ and content of $\mathrm{Pb}$ and $\mathrm{Cu}$.

Heavy metal content, such as $\mathrm{Pb}, \mathrm{Cr}, \mathrm{Cu}, \mathrm{Co}, \mathrm{Ni}$ and $\mathrm{Zn}$ was analyzed for a selected set of samples $(N=39$, Table 3$)$ (Lourenço, 2003). The mean levels for $\mathrm{Pb}\left(115 \mathrm{mg} \mathrm{kg}^{-1}\right)$, $\mathrm{Ni}\left(48 \mathrm{mg} \mathrm{kg}^{-1}\right), \mathrm{Zn}\left(387 \mathrm{mg} \mathrm{kg}^{-1}\right)$ and $\mathrm{Cu}\left(78 \mathrm{mg} \mathrm{kg}^{-1}\right)$ are high compared with the average background for global and agricultural land in England (Reimann and Caritat, 1998).

Romic and Romic (2003) studied the heavy metals distribution in agricultural soils from the outskirts of Zagreb (Croatia). They refer the average 
Table 5. Correlation coefficient between heavy metals content and magnetic parameters in topsoils.

\begin{tabular}{rrrrrrrr}
\hline & $\ln \mathrm{Zn}$ & $\ln \mathrm{Ni}$ & $\ln \mathrm{Co}$ & $\ln \mathrm{Cr}$ & $\ln \mathrm{Cu}$ & $\ln \mathrm{Pb}$ \\
\hline & $\ln \chi$ & $0.354^{*}$ & -0.131 & -0.269 & $0.359^{*}$ & $0.370^{*}$ & $0.378^{*}$ \\
\multirow{3}{*}{ Spearman's rho } & $\ln \mathrm{SIRM}$ & 0.165 & -0.148 & $-0.324^{*}$ & 0.089 & $0.375^{*}$ & $0.526^{* *}$ \\
& $\ln \mathrm{ARM}$ & $0.359^{*}$ & 0.182 & 0.078 & $0.484^{* *}$ & 0.210 & 0.112 \\
& ln IRM_100 & 0.019 & -0.055 & -0.121 & 0.019 & $0.521^{* *}$ & $0.395^{*}$ \\
& $\ln \mathrm{IRM}_{-300}$ & -0.110 & 0.456 & 0.368 & -0.091 & 0.258 & -0.096 \\
\hline
\end{tabular}

** Correlation is significant at the 0.01 level. * Correlation is significant at the 0.05 level.

values for $\mathrm{Cu}=20.80 \mathrm{mg} \mathrm{kg}^{-1}, \quad \mathrm{Ni}=49.50 \mathrm{mg} \mathrm{kg}^{-1}$, $\mathrm{Pb}=25.90 \mathrm{mg} \mathrm{kg}^{-1}$ and $\mathrm{Zn}=77.90 \mathrm{mg} \mathrm{kg}^{-1}$, for an area with a lot of industry and roads (with high traffic frequency). We also compared our results with the "Soil Geochemical Atlas of Portugal" (Inácio et al., 2008). The range of our values is consistent with those presented in that study, however, mean values are once again higher than those considered in the referred study (Table 4). The existence of a nearby ancient town (the town of Coimbra has a recorded history that goes back over $2000 \mathrm{yr}$ ) may also explain the observed values for some elements due to the phenomenon of accumulation over time. In agricultural soils, the high values may be related to the intensive use of chemical products like herbicides, fungicides and fertilizers.

Table 5 lists the correlation between magnetic parameters and heavy metals ( $\mathrm{Pb}, \mathrm{Zn}, \mathrm{Cd}, \mathrm{Cu}, \mathrm{Ni}$ and $\mathrm{Cr}$ ). Results show that significant correlation exists between heavy metals and $\chi$, ARM, SIRM and IRM-100 mT. The correlation between the contents of heavy metals and $\chi$ was 0.378 for $\mathrm{Pb}, 0.370$ for $\mathrm{Cu}, 0.359$ for $\mathrm{Cr}$ and 0.354 for $\mathrm{Zn}$. These correlations are significant at level 0.05. Positive correlations between the magnetic susceptibility and heavy metals concentration have been reported in literature (e.g. Blaha et al., 2008; Chaparro et al., 2008; Rosowiecka and Nawrocki, 2010; El Baghdadi et al., 2011). However, better correlations are found between heavy metals contents and remanent parameters. A similar result was reported by $\mathrm{Lu}$ and Bai, 2006. The correlations between SIRM and Pb, ARM and Cr, and IRM $-100 \mathrm{mT}$ and $\mathrm{Cu}$ are significant at 0.01 level. Correlations significant at 0.05 level are found between SIRM and $\mathrm{Cu}$, SIRM and Co (the correlation is negative but significant at the 0.05 level), ARM and $\mathrm{Zn}$ and IRM-100 $\mathrm{mT}$ and $\mathrm{Pb}$.

The correlation between SIRM (IRM $\left.\mathrm{IT}_{\mathrm{T}}\right)$ and this group of metals was also analysed. In this case, the highest correlation was observed for $\mathrm{Pb}$ and $\mathrm{Cu}$ ( $r$ of Spearman $=0.5$ and 0.4 , correlations are significant at 0.01 level and 0.05 level) (Fig. 10).

The XRD analysis (Table 6) shows that the mineral suites consist mainly of quartz (Qz), phyllossilicates $(\mathrm{F}), \mathrm{k}$ feldspars (Fk), plagioclases (P), calcite (C), dolomite (D) and siderite (Sy). Some samples have small quantities of magnetite/maghemite $(<2 \%)$. This result corroborates with the findings of other authors (Chaparro et al., 2002).
Table 6. Mineral composition of soil samples (\%).

\begin{tabular}{lrr}
\hline Minerals & Range & $M$ \\
\hline F & $45-3$ & 24 \\
Qz & $56-23$ & 38 \\
Fk & $30-3$ & 11 \\
P & $60-1$ & 16 \\
C & $24-1$ & 11 \\
D & $24-1$ & 7 \\
Sy & $5-3$ & 4 \\
\hline
\end{tabular}

$\mathrm{F}=$ phyllossilicates, $\mathrm{Qz}=$ quartz, $\mathrm{Fk}=\mathrm{k}$-feldspars, $\mathrm{P}=$ plagioclases, $\mathrm{C}=$ calcite, $\mathrm{D}=$ dolomite and $\mathrm{Sy}=$ siderite $M-$ arithmetic mean.

Other samples show traces of plumbogummite and jarosite. In nature, plumbogummite has been found in several locations as a secondary mineral in the oxidized zones of lead deposits. It is also a common constituent of soils, and it is believed to be the end product in the weathering of inorganic soil phosphorus (Sarma and Murti, 1970; Nriagu, 1974). In this study, we consider that the existence of this mineral is probably related with an ancient lead mining site upstream Mondego river in the village of Zorro, near Coimbra (Pratas, 1996).

The clay fraction of the analyzed soils is characterized by a rather uniform clay mineral assemblage. The XRD analysis shows that illite (average $52 \%$ ), kaolinite (average $55 \%$ ), chlorite (average 6\%) and irregular illite-smectite mixedlayers (average $9 \%$ ) are the major clay mineral groups identified. These results are similar to the clay mineral suite observed in the Aveiro shelf (Abrantes and Rocha, 2007). No significant correlations are found between clay mineralogy and the magnetic data.

Correlations between $R$ index (calculated for the main clay minerals) and the magnetic parameters show significant correlation between $R_{\text {ill }}$ ( $R$ calculated for illite) and $S_{-300 \mathrm{mT}}$ (the correlation is negative but significant at the 0.05 level), between $R_{\text {chl }}$ ( $R$ calculated for chlorite) and ARM, and between $R_{\text {kaol }}$ ( $R$ calculated for kaolinite) and ARM. These correlations are significant at 0.05 level. Correlations between $R$ index and heavy metals show significant correlation between $R_{\mathrm{ill}}$ and Co content, and between $R_{\mathrm{chl}}$ and $\mathrm{Cr}$ content (correlations are significant at 0.05 level and at 
Table 7. Spearman's correlations between $R$ index and magnetic parameters and content of toxic metals.

\begin{tabular}{|c|c|c|c|c|c|c|c|c|c|c|c|c|c|}
\hline $\begin{array}{l}R \\
\text { index }\end{array}$ & $\chi$ & SIRM & $\begin{array}{r}\text { IRM } \\
-100 \mathrm{mT}\end{array}$ & $\begin{array}{r}\text { IRM } \\
-300 \mathrm{mT}\end{array}$ & ARM & $\begin{array}{r}S \\
-300 \mathrm{mT}\end{array}$ & $\begin{array}{r}S \\
-100 \mathrm{mT}\end{array}$ & $\mathrm{Zn}$ & $\mathrm{Ni}$ & $\mathrm{Co}$ & $\mathrm{Cr}$ & $\mathrm{Cu}$ & $\mathrm{Pb}$ \\
\hline$R_{\text {ill }}$ & -0.148 & -0.163 & -0.370 & -0.182 & 0.149 & $-0.618^{*}$ & -0.321 & -0.240 & 0.160 & $0.441 *$ & 0.184 & 0.149 & -0.123 \\
\hline$R_{\mathrm{chl}}$ & 0.199 & 0.135 & 0.014 & 0.209 & $0.385^{*}$ & 0.291 & -0.099 & 0.213 & 0.168 & 0.219 & $0.510 * *$ & 0.063 & 0.204 \\
\hline$R_{\text {kaol }}$ & -0.229 & -0.303 & $-0.409^{*}$ & -0.009 & 0.213 & 0.291 & -0.034 & 0.164 & 0.236 & 0.285 & 0.249 & -0.035 & -0.158 \\
\hline
\end{tabular}

* Correlation is significant at the 0.05 level. ** Correlation is significant at the 0.01 level.

0.01 level, respectively) (Table 7). The degree of crystallinity has an important bearing on the scavenging of heavy metals by secondary minerals (such as clay minerals, sulfites, sulphates oxides and hydroxides) as poorly crystallized minerals are more efficient sorbents than crystalline ones. In particular, illite crystallochemical characteristics show good correlations with the distribution of some metals, pointing to a role of this mineral (in particular, under specific crystallochemical conditions) in their fixation. Actually, the order/disorder degree of their crystallographic structures and the type of octahedral composition ( $\mathrm{Al}$ rich versus $\mathrm{Fe}-\mathrm{Mg}$ rich) of the illites exert important control on the metal fixation.

\section{Conclusions}

Spatial variation of magnetic susceptibility shows a characteristic distribution with higher values near roads and streams. Near roads, these values are associated with ferrimagnetic material produced by car traffic. Near streams, the reason for the high values lies in the accumulation of antropogenic magnetic particles during floods. The analysis of IRM acquisition curves suggests that the main magnetic phases present in the samples are ferrimagnetic structures (e.g. magnetite/maghemite). The " $S$-ratios" calculated suggest the same conclusion.

Our results demonstrated that magnetic susceptibility has a good correlation with heavy metals so this parameter can be used as a proxy for soil pollution; however, remanent magnetic parameters are better indicators for heavy metal pollutions than magnetic susceptibility is in studied area; also SIRM, ARM and IRM-100 $\mathrm{mT}$ can be used as proxy method for monitoring the contents of toxic metals in topsoils in this area.

The results of XRD analyses show that the most abundant minerals are quartz, phyllossilicates, k-feldspars, plagioclases, calcite and dolomite. They also confirm the presence of magnetite/maghemite although with a concentration generally below $2 \%$. Some samples show traces of plumbogummite. Clay fractions are characterized by a rather uniform clay mineral assemblage, illite, kaolinite, chlorite and irregular illite-smectite mixed-layers being the major clay mineral groups identified, but no correlation is found between magnetic parameters and clay minerals. The new calculated index, $R$, showed good correlation with magnetic parameters and with $\mathrm{Co}$ and $\mathrm{Cr}$ contents.

Our study showed that magnetic mapping is a sensitive, fast and robust method, which can be advantageously applied to regions affected by urban and road pollution.

Acknowledgements. This study was supported by the Portuguese Government through the Foundation for Science and Technology FCT, within the PEst-OE/CTE/UI0611/2012 Project of the Centre for Geophysics of the University of Coimbra - CGUC. Marcos Chaparro, Ana María Sinito and two anonymous reviewers are thanked for the constructive reviews and suggestions.

Edited by: A. M. Tarquis

Reviewed by: M. Chaparro, J. Paz-Ferreiro, A. M. Sinito, and another anonymous referee

\section{References}

Abrantes, I. and Rocha, F.: Sedimentary Dynamics of the Aveiro Shelf (Portugal), J. Coast. Res., SI 50 (Proceedings of the 9th International Coastal Symposium), Gold Coast, Australia, 10051009, 2007.

Alagarsamy, R.: Environmental magnetism and application in the continental shelf sediments of India, Mar. Environ. Res., 68, 4958, 2009.

Bityukova, L., Scholger, R., and Birke, M.: Magnetic susceptibility as indicator of environmental pollution of soils in Tallinn, Phys. Chem. Earth, 24, 829-35, 1999.

Blaha, U., Appel, E., and Stanjek, H.: Determination of anthropogenic boundary depth in industrially polluted soil and semiquantification of heavy metal loads using magnetic susceptibility, Environ. Pollut., 156, 278-289, 2008.

Bloemendal, J., King, J. W., Hall, F. R., and Doh, S.-J.: Rock magnetism of Late Neogene and Pleistocene deep-sea sediments: Relationship to sediment source, diagenetic processes, and sediment lithology, J. Geophys. Res., 97, 4361-4375, 1992.

Booth, C. A., Walden, J., Neal, A., and Smith, J. P.: Use of mineral magnetic concentration data as a particle size proxy: A case study using marine, estuarine and fluvial sediments in the Carmarthen Bay area, South Wales, UK, Sci. Total Environ., 347, 241-253, 2005.

Boyko, T., Scholger, R., and Stanjek, H.: MAGPROX Team, Topsoil magnetic susceptibility mapping as a tool for pollution monitoring: repeatability of in situ measurements, J. Appl. Geophys., 55, 249-259, 2004. 
Chaparro, M. A. E., Gogorza, C. S. G., Lavat, A., Pazos, S., and Sinito, A. M.: Preliminary results of magnetic characterisation of different soils in the Tandil region (Argentina) affected by pollution by a metallurgical factory, Eur. J. Environ. Eng. Geophys., 7, 35-58, 2002.

Chaparro, M. A. E., Bigedain, J. C., Sinito, A. M., Jurado, S. S., and Gogorza, C. S. G.: Relevant magnetic parameters and heavy metals from relatively polluted stream sediments - vertical and longitudinal distribution along a cross-city stream in Buenos Aires province, Argentina, Stud. Geophys. Geod., 48, 615-636, 2004.

Chaparro, M. A. E., Gogorza, C. S. G., Chaparro, M. A., Irurzun, M. A., and Sinito, A. M.: Review of magnetism and heavy metal pollution studies of various environments in Argentina, Earth Planet. Space, 58, 1411-1422, 2006.

Chaparro, M. A. E., Sinito, A. M., Ramasamy, V., Marinelli, C., Chaparro, M. A. E., Mullainathan, S., and Murugesan, S.: Magnetic measurements and pollutants of sediments from Cauvery and Palaru River, India, Environ. Geol., 56, 425-437, doi:10.1007/s00254-007-1180-1, 2008.

Dearing, J. A., Hay, K. L., Baban, S. M. J., Huddleston, A. S., Wellington, E. M. H., and Loveland, P. J.: Magnetic susceptibility of soil: An evaluation of conflicting theories using a national data set, Geophys. J. Int., 127, 728-734, 1996a.

Dearing, J. A., Dann, R. J. L., Hay, K., Lees, J. A., Loveland, P. J., Maher, B. A., and O'Grady, K.: Frequency-dependent susceptibility measurements of environmental materials, Geophys. J. Int., 124, 228-240, 1996b.

Dunoyer de Segonzak, G.: Les mineraux argileux dans la diagenèse, Passage au métamorphisme, Mém. 29, Serv. Carte Géol. Als. Lorr., 320 pp., 1969.

Ďurža, O.: Heavy metals contamination and magnetic susceptibility in soils around metallurgical plan, Phys. Chem. Earth, Part A Solid Earth Geod., 24, 541-543, 1999.

El Baghdadi, M., Barakat, A., Sajieddine, M., and Nadem, S.: Heavy metal pollution and soil magnetic susceptibility in urban soil of Beni Mellal City (Morocco), Environ. Earth Sci., 1-15, doi:10.1007/s12665-011-1215-5, 2011.

F.A.O: World reference base for soil resources. World soil resources Reports, Food and Agriculture Organisation of the United Nations, Rome, 145 pp., 2006.

Flanders, P. J.: Collection, measurements and analysis of airborne magnetic particulates from pollution in the environment, J. Appl. Phys., 75, 5931-5936, 1994.

Flanders, P. J.: Identifying fly ash at a distance from fossil fuel power stations, Environ. Sci. Technol., 33, 528-532, 1999.

Galhano, C., Rocha F., and Gomes C.: Geostatistical analysis of the Influence of textural, mineralogical and geochemical parameters on the geotechnical behavior of the "Clays Aveiro" formation (Portugal), Clay Miner., 34, 109-116, 1999.

Gautam, P., Blaha, U. and Appel, E.: Integration of magnetism and heavy metal chemistry of soils to quantify the environmental pollution in Kathmandu, Nepal, Island Arc, 14, 424-435, 2005.

Gołuchowska, B. J.: Some factors affecting an increase in magnetic susceptibility of cement dusts, J. Appl. Geophys., 48, 103-112, 2001.

Gomes, C. R., Rocha, A. L. F., Neves, L. F., and Rey, D. G.: A influência do tráfego rodoviário na qualidade do ar em meios urbanos: Um estudo na cidade de Coimbra, Actas $2^{\circ}$ Cong. LusoBrasileiro para o Planeamento Urbano, Regional, Integrado e
Sustentável. Pluris 2006, Braga, Portugal, 2006.

Gomes, C. R., Dias, J., Neves, L., Rocha, A., and Gomes, E.: Relationships between magnetic properties and heavy metals in Nerium oleander leaves and soils (Viseu, Central Portugal), Geochim. Cosmochim. Acta, 71, A340-A340, Suppl. S AUG, 2007.

Hanesch, M. and Scholger, R.: Mapping of heavy metal loadings in soils by means of magnetic susceptibility measurements, Environ. Geol., 42, 857-870, 2002.

Hanesch, M. and Scholger, R.: The influence of soil type on the magnetic susceptibility measured throughout soil profiles, Geophys. J. Int., 161, 50-55, 2005.

Hanesch, M., Maier, G., and Scholger, R.: Mapping heavy metal distribution by measuring the magnetic susceptibility of soils, J. Geophys., 107, 605-608, 2003.

Hay, K., Dearing, J., Baban, S., and Loveland, P.: A preliminary attempt to identify atmospherically-derived pollution particles in English topsoils from magnetic susceptibility measurements, Phys. Chem. Earth, 22, 207-210, 1997.

Heller, F., Strzyszcz, Z., and Magiera, T.: Magnetic record of industrial pollution in forest soils of Upper Silesia, Poland, J. Geophys. Res., 103, 17767-17774, 1998.

Hoffmann, V., Knab, M., and Appel, E.: Magnetic susceptibility mapping of roadside pollution, J. Geoch. Explor., 66, 313-326, 1999.

Inácio, M., Pereira, V., and Pinto, M.: The Soil Geochemical Atlas of Portugal: Overview and applications, J. Geoch. Explor., 98, 22-33, 2008.

Jordanova, D., Jordanova, N., Petrov, P., and Tsacheva, Ts.: Soil development of three Chernozem-like profiles from North Bulgaria revealed by magnetic studies, Catena, 83, 158-169, 2010.

Kapička, A., Petrovský, E., Ustjak, S., and Macháčková, K.: Proxy mapping of fly-ash pollution of soils around a coal-burning power plant: a case study in the Czech Republic, J. Geoch. Explor., 66, 291-297, 1999.

Kapička, A., Jordanova, N., Petrovský, E., and Ustjak, S.: Magnetic stability of power-plant fly ash in different soil solutions, Phys. Chem. Earth, 25, 431-436, 2000.

Kapička, A., Petrovský, E., Fialová, H., Podrázský, V., and Dvořák, I.: High resolution mapping of anthropogenic pollution In the Giant Mountains National Park using soil magnetometry, Stud. Geophys. Geod., 52, 271-284, 2008.

Karimi, R., Ayoubi, S., Jalalian, A., Sheikh-Hosseini, A. R., and Afyuni, M.: Relationships between magnetic susceptibility and heavy metals in urban topsoils in the arid region of Isfahan, central Iran, J. Appl. Geophys., 74, 1-7, 2011.

Kim, W., Doh, S. J., and Yu, Y.: Anthropogenic contribution of magnetic particulates in urban roadside dust, Atmos. Environ., 43, 3137-3144, 2009.

Knab, M., Appel, E., and Hoffmann, V.: Separation of the anthropogenic portion of heavy metal contents along a highway by means of magnetic susceptibility and fuzzy c-means cluster analysis, Eur. J. Environ. Eng. Geophys., 6, 125-140, 2001.

Kübler, B.: Les argiles, indicateurs de métamorphisme, Rev. Inst. Fr. Pétrole, 19, 1093-1112, 1964.

Lapa, M. and Reis, R.: Contribuição para o estudo dos minerais argilosos em formações sedimentares da Orla Meso-Cenozóica Ocidental. Mem. e Not., Publ. Mus. Lab. Min. Geol., 83, 3-35, 1977. 
Lecoanet, H., Lévêque, F., and Segura, S.: Magnetic susceptibility in environmental applications: comparison of field probes, Phys. Earth Planet. Int., 115, 191-204, 1999.

Lecoanet, H., Lévêque, F., and Ambrosi, J. P.: Magnetic properties of salt-marsh soils contaminated by iron industry emissions (southeast France), J. Appl. Geophys., 48, 67-81, 2001.

Liu, Q., Roberts, A., Torrent, J., Horng, C., and Larrasoaña, J.: What do the HIRM and S-ratio really measure in environmental magnetism?, Geoch. Geophy. Geosyst., 8, Q09011, doi:10.1029/2007GC001717, 2007.

Lourenço, A. M.: Parâmetros magnéticos de solos na periferia da área urbana de Coimbra, Dissert. Mest., F.C.T., Univ. Coimbra, 154 pp., 2003.

Lourenço, A. M., Sant'Ovaia, H., Sequeira, E. M., and Gomes, C. R.: Magnetic, pedological and geochemical characterization of the soils in the periphery of Coimbra, central Portugal, Proceedings of the VIII Iberian Geochemistry Conference, Castelo Branco, Portugal, 24-28 September, 407-410, 2011.

Lu, S. G. and Bai, S. Q.: Study on the correlation of magnetic properties and heavy metals content in urban soils of Hangzhou City, China. J. App. Geophys., 60, 1-12, 2006.

Lu, S. G., Wang, H. Y., and Bai, S. Q.: Heavy metal contents and magnetic susceptibility of soils along an urban-rural gradient in rapidly growing city of eastern China, Environ. Monit., 155, 91101, doi:10.1007/s10661-008-0420-5, 2009.

Maher, B. A.: Characterisation of soils by mineral magnetic measurements, Phys. Earth Plan. Int., 42, 76-92, 1986.

Maher, B. A., Moore, C., and Matzka, J.: Spatial variation in vehicle-derived metal pollution identified by magnetic and elemental analysis of roadside tree leaves, Atmos. Environ., 42, 364-373, 2008.

Marié, D. C., Chaparro, M. A. E., Gogorza, C. S. G., Navas, A., and Sinito A. M.: Vehicle-derived emissions and pollution on the road Autovia 2 investigated by rock-magnetic parameters: a case of study from Argentina, Stud. Geophys. Geod., 54, 135152,2010

Martins, V., Dubert, J., Jouanneau, J., Weber, O., Ferreira, E., Patinha, C., Dias, J., and Rocha, F.: A multiproxy approach of the Holocene evolution of shelf-slope circulation on the NW Iberian Continental Shelf, Mar. Geol., 239, 1-18, 2007.

Matýsek, D., Raclavská, H., and Raclavský, K.: Correlation Between Magnetic Susceptibility and Heavy Metal Concentrations in Forest Soils of the Eastern Czech Republic, J. Environ. Eng. Geophys., 13, 13-26, 2008.

Meena, N. K., Maiti, S., and Shrivastava, A.: Discrimination between anthropogenic (pollution) and lithogenic magnetic fraction in urban soils (Delhi, India) using environmental magnetism, J. Appl. Geophys., 73, 121-129, 2011.

Mohamed, K. J., Rey, D., Rubio, B., and Vilas, J.: Aplicación de las propriedades magnéticas en el estudio de la diagénesis temprana en sedimentos marinos de la Rías Baixas, Magiber I, Livro de Comunicações, Burgos, Espanha, 2001.

Moreno, E., Sagnotti, L., Dinarès-Turell, J., Winkler, A., and Cascella, A.: Biomonitoring of traffic air pollution in Rome using magnetic properties of tree leaves, Atmos. Environ, 37, 29672977,2003
Nriagu, J. O.: Lead orthophosphates-IV Formation and stability in the environment, Geoch. Cosmochim. Acta, 38, 887-898, 1974.

Oliveira, A., Rocha, F., Rodrigues, A., Jouanneau, J., Dias, A., Weber, O., and Gomes, C.: Clay minerals from the sedimentary cover from the Northwest Iberian shelf, Prog. Oceanogr., 52, 233-247, 2002.

Pratas, J.: Aplicações de prospecção biogeoquímica, Selecção de espécies bioindicadoras em allgumas áreas mineiras de Portugal, Dissert. Dout., Univ. Coimbra, 1064 pp., 1996.

Petrovský, E., Kapička, A., Jordanova, N., Knab, M., and Hoffmann, V.: Low-field magnetic susceptibility: a proxy method of estimating increased pollution of different environmental systems, Environ. Geol., 39, 312-318, 2000.

Reimann, C. and Caritat, P.: Chemical elements in the environment, Springer-Verlag, 398 pp., 1998.

Romic, M. and Romic, D.: Heavy metals distribution in agricultural topsoils in urban area, Environ. Geol., 43, 795-805, 2003.

Rosowiecka, O. and Nawrocki, J.: Assessment of soils pollution extent in surroundings of ironworks based on magnetic analysis, Stud. Geophys. Geod., 54, 185-194, 2010.

Sarma, V. A. and Murti, G. S.: Plumbogummite minerals in Indian soils, Geoderma, 3, 321-327, 1970.

Schibler, L., Boyko, T., Ferdyn, M., Gajda, B., Höll, S., Jordanova, N., and Rösler, W., MAGPROX Team: Topsoil magnetic susceptibility mapping: Data reproducibility and compatibility, measurement strategy, Stud. Geophys. Geod., 46, 43-57, 2002.

Scholger, R.: Heavy metal pollution monitoring by magnetic susceptibility measurements applied to sediments of the river Mur (Styria, Austria), Eur. J. Environ. Eng. Geophys., 3, 25-37, 1998.

Strzyszcz, Z. and Ferdyn, M.: Magnetic susceptibility and heavy metal content of soil around the coking plants in Silesia, Mitt. Deut. Boden. Ges., 107, 557-558, 2005.

Strzyszcz, Z., Magiera, T., and Heller, F.: The influence of industrial immissions on the magnetic susceptibility of soils in Upper Silesia, Stud. Geophys. Geod., 40, 276-286, 1996.

Thompson, R., Bloemendal, J. A., Dearing, J., Oldfield, F., Rummery, T. A., Stober, J. C., and Turner, G. M.: Environmental Applications of Magnetic Measurements, Science, 207, 481-486, 1980.

Veneva, L., Hoffmann, V., Jordanova, D., Jordanova, N., and Fehr, T.: Rock magnetic, mineralogical and microstructural characterization of fly ashes from Bulgarian power plants and the nearby anthropogenic soils, Phys. Chem. Earth, 29, 1011-1023, 2004.

Walden, J. and Ballantyne, C.: Use of environmental magnetic measurements to validate the vertical extent of ice masses at the Last Glacial Maximum, J. Quaternary Sci., 17, 193-200, 2002.

Yang, T., Liu, Q., Zeng, Q., and Chan, L.: Relationship between magnetic properties and heavy metals of urban soils with different soil types and environmental settings: implications for magnetic mapping, Environ. Earth Sci., 1-12, doi:10.1007/s12665011-1248-9, 2011. 